\title{
Tepraloxydim, fluazifop-p-butyl ve metribuzin herbisitlerinin toprak kökenli bazı fungal patojenlerin koloni gelişimine ve sporulasyonuna etkisi ${ }^{1}$
}

\author{
Gürhan MUTLU $^{2} \quad$ Tamer ÜSTÜNER ${ }^{3}$
}

\begin{abstract}
Effect of the herbicide tepraloxydim, fluazifop-p-butyl and metribuzin on the colony growth and sporulation of some soilborne fungal pathogens
\end{abstract}

The objective of this study was to analyze the effect of herbicides tepraloxydim, fluazifopp-butyl and metribuzin on colony development and sporulation of some important fungi in in vitro and greenhouse conditions. At the end of the study, tepraloxydim at high dose of $2 \times 10^{-3} \mathrm{M}$ prevented Rhizoctonia solani colony growth at the highest level with the rate of $(88.93 \%)$. Tepraloxydim at $5 \times 10^{-5} \mathrm{M}$ inhibited $R$. solani colony growth at the lowest level with the rate of $(0.21 \%)$. However, the growth rate of Phoma destructiva could not be decreased at this low dose level, but increased the growth of colony by (1.29\%). As a result of study, the colony development of $R$. solani in in vitro conditions was completely inhibited at high dose application $\left(2 \times 10^{-3} \mathrm{M}\right)$ of fluazifop-p-butyl. At low dose $\left(5 \times 10^{-5} \mathrm{M}\right)$ application of herbicide, the colony development of $P$. destructiva was decreased by (4.68\%) at the lowest dose level, but increased colony development of Rhizopus stolonifer by $(4.14 \%)$. Metribuzin prevented colony development of $R h$. stolonifer at the highest dose level of $2 \times 10^{-3} \mathrm{M}$ by $(63.47 \%)$ and the highest dose of application in in vitro conditions, It also prevented the development of Cladosporium fulvum at the lowest level $(2.51 \%)$ when applied at $5 \times 10^{-5} \mathrm{M}$. Tepraloxydim at above and below (50\%) affected sporulation of fungal pathogens with Alternaria alternata most affected $\left(1.2 \times 10^{2}\right.$ spore $/ \mathrm{ml} ; 2.7 \times 10^{2}$ spore $\left./ \mathrm{ml}\right)$ under greenhouse conditions. High dose (above concentrations of 50\%) application of fluazifop-p-butyl mostly affected Stemphylium solani $\left(1.6 \times 10^{2} \mathrm{spore} / \mathrm{ml}\right)$ in greenhouse

${ }^{1} \mathrm{Bu}$ çalışma Kahramanmaraş Sütçü İmam Üniversitesi, Fen Bilimleri Enstitüsü tarafindan kabul edilen "Elazı̆̆ Bölgesi domates üretim alanlarında kullanılan tepraloxydim, fluazifop-P butyl ve metribuzin aktif maddeli herbisitlerin toprak kökenli fungal patojenlerin in vitro gelişimine etkisi" adlı yüksek lisans tezinin bir bölümüdür ve KSÜBAP tarafindan desteklenmiștir (Proje No: 2014/213YLS).

${ }^{2}$ Frrat Üniversitesi, Keban Meslek Yüksekokulu, 23700, Keban / Elazı ğ

${ }^{3}$ K.S.Ü., Ziraat Fakültesi, Bitki Koruma Bölümü, 46040, Kahramanmaraş

Sorumlu yazar (Corresponding author) e-mail: gmutlu@ firat.edu.tr

Alınış (Received): 09.08.2016, Kabul ediliş (Accepted): 07.02.2017 
Tepraloxydim, fluazifop-p-butyl ve metribuzin herbisitlerinin toprak kökenli bazı fungal patojenlerin koloni gelişimine ve sporulasyonuna etkisi

conditions. A. alternata $\left(3.0 \times 10^{2}\right.$ spore/ml) was the mostly influenced pathogen for fungal sporulation at low dose (below 50\%) application of fluazifop-p-butyl herbicide. High dose application of metribuzin mostly affected Fusarium solani and Rh. stolonifer in greenhouse. The total number of spores determined at the last count for $F$. solani and $R h$. stolonifer was $\left(2.5 \times 10^{2}\right)$ spore/ml. The number of A. alternata spores at low dose application was $\left(4.1 \times 10^{2}\right) \mathrm{spore} / \mathrm{ml}$.

Keywords: Tomato, herbicide, tepraloxydim, fluazifop-p-butyl, metribuzin, fungal pathogens, sporulation

\section{ÖZ}

$\mathrm{Bu}$ çalışmanın amacı, in vitro ve sera koşullarında bazı önemli mantarların koloni gelişimi ve sporulasyonu üzerine tepraloxydim, fluazifop-p-butyl ve metribuzin herbisitlerinin etkisini analiz etmektir. Çalışma sonucunda tepraloxydim $2 \times 10^{-3} \mathrm{M}$ yüksek dozda Rhizoctonia solani'nin koloni gelişimini \%88.93 oranı ile en üst düzeyde engellemiştir. Tepraloxydim $5 \times 10^{-5} \mathrm{M}$ 'de, $\% 0.21$ oranı ile $R$. solani'nin koloni gelişimini en düşük seviyede engellemiştir. Bununla birlikte, tepraloxydim'in düşük doz seviyesinde Phoma destructiva'nın büyüme oranında azalma olmayıp, koloni gelişimini (\%1.29) artırmıştır. Çalışmanın sonucunda, in vitro koşullarda fluazifop-P-butyl'in yüksek doz uygulamasında $2 \times 10^{-3} \mathrm{M} R$. solani'nin koloni gelişimini tamamen engellenmiştir. Herbisitin düşük doz $5 \times 10^{-5} \mathrm{M}$ uygulaması, $P$. destructiva koloni gelişimini en düşük doz seviyesinde $(\% 4.68)$ azaltmış, ancak Rhizopus stolonifer'in koloni gelişimini (\%4.14) artırmıştır. In vitro koşullarda metribuzin'in yüksek doz $2 \times 10^{-3} \mathrm{M}$ uygulamasında $R h$. stolonifer' in koloni gelişimini en yüksek seviyede (\%63.47) engellediği ve ayrıca en düşük doz $5 \times 10^{-5} \mathrm{M}$ uygulamasında Cladosporium fulvum'u en düşük seviyede gelişimini (\%2.51) engellemiştir. Sera koşullarında tepraloxydim'in yüksek doz (\%50 fazla) ve düşük doz (\%50 düşük) uygulamalarında sporulasyonu en çok etkilenen fungal patojen Alternaria alternata $\left(1.2 \times 10^{2} \mathrm{spor} / \mathrm{ml} ; 2.7 \times 10^{2} \mathrm{spor} / \mathrm{ml}\right)$ 'dır. Sera koşullarında yüksek doz (\%50 fazla) uygulamasında fluazifop-p-butyl'in en çok etkilediği patojen Stemphylium solani $\left(1.6 \times 10^{2}\right.$ spor/ml)'dir. Fluazifop-p-butyl herbisitin düşük doz (\%50 düşük) uygulamasında fungal sporulasyonu en çok etkilenen patojen A. alternata $\left(3.0 \times 10^{2}\right.$ spor $\left./ \mathrm{ml}\right)$ 'dır. Serada metribuzin yüksek doz uygulaması çoğunlukla Fusarium solani ve Rh. stolonifer'i etkilemiştir. F. solani ve $R h$. stolonifer'in son sayıma göre belirlenen toplam spor sayıları $2.5 \times 10^{2}$ spor/ml'dir. Düşük doz uygulamasında A. alternata sporlarının sayıı $4.1 \times 10^{2}$ spor/ml'dir.

Anahtar kelimeler: Domates, herbisit, tepraloxydim, fluazifop-p-butyl, metribuzin, fungal patojenler, sporulasyon

\section{GíRis}

Türkiye'de ve Dünya'da sebze tarımı çok önemli bir konuma sahiptir. Bu sebzelerden bazılarının yetiştiriciliğinin kolay olması, bazılarının ekonomik değeri, bazılarının da içerdiği besin maddelerinin insanlar yönünden değerli olması nedeniyle yetiştiricilikleri ön plandadır. Domates yetiştiriciliğinde verim ve kaliteyi etkileyen birçok faktör mevcuttur. Bunlar arasında fungal patojenlerin ve yabanc1 otların domates yetiştiriciliğinde meydana getirdiği kayıplar önem arz etmektedir. 
Son yıllarda gerek kullanım kolaylığı, gerekse düşük işçilik maliyetinden dolayı domates yetiştiriciliğinde yabancı otlarla mücadelede herbisit kullanımı yaygınlaşmaya başlamıştır. Herbisit uygulamalarındaki bu artış fitopatolojik açıdan birçok yan etkileri de beraberinde getirmektedir. Herbisitlerin bilinçsizce ve etiket bilgisinin dışında aşırı dozda kullanılmaları sonucunda, esas hedef dışındaki canlılar ve diğer çevre unsurları da bundan olumsuz yönde etkilenmektedir (Şevik ve ark. 2004, Torun ve ark. 2011). Yapılan bir çalışmada Domsch et al. (1983), toprağa uygulanan pestisitlerin, topraktaki bazı enzimlerin aktivitesini etkileyici bir şekilde yaptığı bileşikler yoluyla toksik etki göstererek, topraktaki mikroorganizmaların ölmesine neden olabileceklerini veya yaşam alanlarını sınırlaya bileyeceğini bildirmişlerdir.

Elham and Mansoor (2013)'de yaptıkları çalışmada trifluralin, ethalfluralin, alachlor ve metribuzin etken maddeli dört herbisitin pamuk ve soya fasulyesi yetiştiriciliğinde zarara neden olan $R$. solani'nin anastomosiz gruplarındaki misel gelişimine etkilerini in vitro şartlarda araştırmış, metribuzin içeren PDA ortamında $R$. solani'nin misel gelişimini tamamen engellemediğini, ancak etkilediğini bildirmişlerdir.

Ecevit ve ark. (1999), yabancı otlarla mücadele amacıyla uygulanan çeşitli herbisitlerin bazı hastalık etmenlerinin artışına, bazılarının ise azalmasına neden olduğunu bildirmişlerdir. Araştırıcılar, genel olarak hormon terkipli herbisitlerin kullanılması ile bitkilerin hastalıklara duyarlılığında bir artış meydana geldiğini, hormon terkipli ilaçların bitki bünyesine alınmasından sonra bitki bünyesinde şeker miktarının ve dolayısıyla yapraklarda serbest haldeki sakkaroz miktarının arttığı ve bunun sonucunda patojenlerin enfeksiyon oluşumunu kolaylaştırdığını saptamışlardır.

Trifluralin ve acetochlor herbisitlerinin $F$. oxysporum f. sp. melonis (FOM)'in miseliyal gelişimi ve kavunda Fusarium solgunluk hastalığ üzerine olan etkileri Akgül ve Canıhoş (2002) tarafından araştırılmıştır. Acetochlor'un koloni gelişimi ve miseliyal gelişim üzerinde, trifluralin'den daha fazla engelleyici etki gösterdiği ve sıvı ortamda doz artışına paralel olarak fungusun miseliyal ağırlı̆̆ını ters orantılı bir şekilde azalttığı tespit edilmiştir. Ayrıca herbisitlerin solgunluk hastalığına olan etkilerinde ise trifluralin ve acetochlor'un uygulama dozlarının yarısının $\left(96 \mu \mathrm{l} / \mathrm{m}^{2}\right.$ trifluralin ve $168 \mu \mathrm{l} / \mathrm{m}^{2}$ acetochlor) hastalığı azaltmada en etkili dozlar olduğu bildirilmiştir. Adı geçen çalışmada trifluralin'in $96 \mu \mathrm{l} / \mathrm{m}^{2} 1 \mathrm{lik}$ dozu hastalık oluşumunu \%62.4 azaltırken, acetochlor'un $168 \mu 1 / \mathrm{m}^{2}$ lik dozunun hastalığ $\% 55$ oranında azalttığ ve herbisitlerin normal uygulama dozlarında $\left(192 \mu 1 / \mathrm{m}^{2}\right.$ ve 336 $\left.\mu 1 / \mathrm{m}^{2}\right)$ hastalık oluşumunu azalttığı ancak iki katı dozlarda ise $\left(384 \mu 1 / \mathrm{m}^{2}\right.$ ve 672 $\mu \mathrm{l} / \mathrm{m}^{2}$ ) hastalığı arttırdığı saptanmıştır.

$\mathrm{Bu}$ araştırmanın amacı, domates üretim alanlarında görülen bazı toprak kökenli fungal hastaliklar ile tepraloxydim, fluazifop-p-butyl ve metribuzin etken maddeli herbisitler arasındaki etkileşimi ortaya çıkarmaktır. 
Tepraloxydim, fluazifop-p-butyl ve metribuzin herbisitlerinin toprak kökenli bazı fungal patojenlerin koloni gelişimine ve sporulasyonuna etkisi

MATERYAL VE METOT

\section{Materyal}

Sera: Deneme, $207 \mathrm{~m}^{2}$ alana sahip, havalandırma oranı \%35 olan Venlo tipi cam serada yürütülmüştür.

Sulama: Sulamalar, lateraller iki bitki sırasının arasına döşenecek ve damlatıcı debisi 2 1/sa, damlatıcı aralığ $30 \mathrm{~cm}$ olan damla sulama sistemiyle yapılmıştır. Bitkilerin seraya şaşırtılmasının hemen ardından 10 1/bitki can suyu uygulanmıştır. Sulama zamanının belirlenmesinde tansiyometrelerden yararlanılmıştır. Damla sulamaya verilen su miktarının ölçümü bir su sayacı yardımıyla yapılmıştır.

Fungal mikroorganizmalar: Elazığ' da 2012-2014 yılları arasında yürütülen bu çalışmada, domates üretim alanlarında yetiştirilen domates bitkisinden elde edilen, yüksek virülanslıklara sahip Stemphylium solani (\%82), Fusarium solani (\%79), Alternaria alternata (\%78), Phoma destructor (\%77), Rhizoctonia solani (\%75) Ulocladium atrum (\%73), Rhizopus stolonifer (\%70) ve Cladosporium fulvum (\%69) izolatları kullanılmıştır.

Besi ortamı: Mikroorganizmaların çoğaltılmasında ve gelişimine etkinin saptanmasında birçok fungal bitki patojeni için standart besi yeri olan PDA [39 g Potato Dextrose Agar (Merck KGaA, Darmstadt, Almanya), 0.02 g Streptomycin sülfat (İ.E Ulugay, İstanbul), $1000 \mathrm{ml}$ saf su] kullanılmıştır.

Herbisitler: Ülkemizde Darıcan (Echinochloa crus-galli)'a karşı ruhsatlı tepraloxydim (Emülsiyon Konsantre, Basf), fluazifop-p-butyl (Emülsiyon Konsantre, Syngenta) ve metribuzin (Islanabilir toz, Hektaş) etkili maddeye sahip herbisitler kullanılmıştır.

Bitki materyali: Denemede, özel bir firmaya (Asgen, İstanbul) ait olan standart H2274 çeşidi domates kullanılmıştır. Elazı̆̆ ilinde açık arazide bu bitkinin bol dökümlü, güçlü bitki yapısına sahip olması ve toprak seçiciliğinin olmamasından dolayı tercih edilmiştir.

\section{Metot}

\section{Araştırmanın yürütüldüğü yıllarda seradaki toprak özellikleri}

Denemenin yürütüldüğü sera alanlarındaki toprakların bünye analizleri, Bouyoucos hidrometre yöntemi (Bouyoucos 1951) ile yapılmıştır. Elde edilen sonuçlara göre sera topraklarının tüm katmanları yüksek oranda kum içeriklidir.. Bu topraklar, orta derecede geçirgenliğe sahip, su tutma kapasiteleri düşük topraklar olarak nitelendirilmektedir. 
In vitro şartlarda tepraloxydim, fluazifop-p-butyl ve metribuzinin koloni gelişimine etkilerinin belirlenmesi

In vitro șartlarda herbisitlerin besi yerine katılımı ve fungal ekim

Araştırmada, otoklavda $\left(121^{\circ} \mathrm{C}\right.$ 'de 15 dakika) sterilize edilen ve $50-60^{\circ} \mathrm{C}^{\prime}$ ye soğutulan, PDA besi yerine tepraloxydim, fluazifop-p-butyl ve metribuzin $2 \times 10^{-3}$ $\mathrm{M}$ (yüksek doz, Yd), $1 \times 10^{-3} \mathrm{M}$ (normal $\mathrm{doz}, \mathrm{Nd}$ ) ve $5 \times 10^{-5} \mathrm{M}$ (düşük doz, Dd) dozlarında otomotik pipet kullanılarak ilave edilmiştir (Çizelge 1). PDA besi yerinde geliştirilen kolonilerden, büyümenin devam ettiği uç kısımlarından, mantar delici ile $5 \mathrm{~mm}$ çaplı diskler alınarak, herbisit içeren PDA besi ortamının ortasına temas edecek şekilde birer adet disk aktarılmıştır. Petriler $25 \pm 1^{\circ} \mathrm{C}$ 'de inkübe edilmiştir.

\section{In vitro şartlarda herbisitlerin etki süreci ve takibi}

Fungus koloni ölçümleri dijital kumpas ile günlük olarak yapılmıştır. Patojenin petri içerisindeki koloni ölçümleri yapılırken, koloni tam çaplı olmadığında koloninin yönleri dikkate alınmış ve ölçüm değerleri toplanıp, ölçüm sayısına bölünerek patojenin uzunluğu hesaplanmıştır (Boyraz ve Özcan 1997, Aktaş ve Şimşek 2005). Koloni çapının ölçümü fungus koloni çapının birbirine dik ayrı yönde ölçülmesi ile yapılmıştır (Benjilali et al. 1984). Kontrollere göre herbisitin fungal gelişime etkisi (\% engelleme oranı) aşağıdaki formül yardımıyla hesaplanmıştır (Deans and Svoboda 1990).

\section{Virülenslik yüzde değeri}

Patojenlerin virülenslik değerleri; sürvey alanından elde edilen hastalık etmenine ait zarar derecelendirilmesi yapılmış toplam bitki sayısı adet bazında belirlenerek, toplam bitki sayısına bölünmesi sonucunda aşağıdaki formüle göre hesaplanmıştır (Karman 1971). Towsend-Heuberger formülü modifiye edilerek kullanılmıştır.

$V(\%)=\sum\left(\frac{B}{A}\right) X 100$

V: virülens değeri (\%);

A: Toplam bitki sayısı (Adet);

B: Hastalık etmenine ait zarar derecelendirilmesi yapılmış toplam bitki sayısı (Adet)

Fungal gelişimi engelleme oranı

$E=\frac{K-M}{K} X 100$

$\mathrm{E}=$ Engelleme oran $1(\%)$;

$\mathrm{K}=$ Kontrolde koloni çap $1(\mathrm{~mm})$;

$\mathrm{M}=$ Uygulamadaki koloni çapı (mm) 
Tepraloxydim, fluazifop-p-butyl ve metribuzin herbisitlerinin toprak kökenli bazı fungal patojenlerin koloni gelişimine ve sporulasyonuna etkisi

Değerlendirmelerin doğruluğunu kontrol etmek için denemeler süresince gelişme göstermeyen fungusların misel parçaları, herbisit içermeyen steril PDA ortamlarında bir hafta süreyle gözlenmiştir. Bu süre sonunda herhangi bir fungal koloni gelişimi olup olmadığı gözlenerek sonuçlar kaydedilmiştir. Deneme tesadüf parselleri deneme deseninde 4 karakter ( 3 farklı doz + kontrol) ve 3 tekerrürlü olarak yürütülmüştür (Boyraz ve Koçak 2006, Erdoğan ve ark. 2014).

Çizelge 1. Denemede kullanılan aktif maddeler, formülasyon şekilleri ve dozları

\begin{tabular}{|c|c|c|c|c|}
\hline \multirow{2}{*}{$\begin{array}{l}\text { Aktif Madde ve } \\
\text { Formülasyon }\end{array}$} & \multirow{2}{*}{$\begin{array}{l}\text { In vitro/In } \\
\text { vivo }\end{array}$} & \multicolumn{3}{|c|}{ Dozlar } \\
\hline & & Yd & Nd & Dd \\
\hline \multirow{2}{*}{$\begin{array}{c}\text { Tepraloxydim } 50 \mathrm{~g} / 1 \\
(\mathrm{SL})\end{array}$} & In vitro & $2 \times 10^{-3} \mathrm{M}$ & $1 \times 10^{-3} \mathrm{M}$ & $5 \times 10^{-5} \mathrm{M}$ \\
\hline & In vivo & $10.05 \mathrm{ml} / \mathrm{da}$ & $6.7 \mathrm{ml} / \mathrm{da}$ & $3.35 \mathrm{ml} / \mathrm{da}$ \\
\hline \multirow{2}{*}{$\begin{array}{l}\text { Fluazifop-p-butyl } \\
\qquad(\mathrm{EC})\end{array}$} & In vitro & $2 \times 10^{-3} \mathrm{M}$ & $1 \times 10^{-3} \mathrm{M}$ & $5 \times 10^{-5} \mathrm{M}$ \\
\hline & In vivo & $7.54 \mathrm{ml} / \mathrm{da}$ & $5.025 \mathrm{ml} / \mathrm{da}$ & $2.51 \mathrm{ml} / \mathrm{da}$ \\
\hline \multirow{2}{*}{$\begin{array}{l}\text { Metribuzin \%70 } \\
\text { (WP) }\end{array}$} & In vitro & $2 \times 10^{-3} \mathrm{M}$ & $1 \times 10^{-3} \mathrm{M}$ & $5 \times 10^{-5} \mathrm{M}$ \\
\hline & In vivo & $7.54 \mathrm{~g} / \mathrm{da}$ & $5.025 \mathrm{~g} / \mathrm{da}$ & $2.51 \mathrm{~g} / \mathrm{da}$ \\
\hline
\end{tabular}

$\mathrm{Yd}$ : in vitro $\mathrm{D}_{1} 2 \times 10^{-3} \mathrm{M} /$ in vivo (\%50 yüksek doz), $\mathrm{Nd}$ : in vitro $\mathrm{D}_{2} 1 \times 10^{-3} \mathrm{M} /$ in vivo (Önerilen doz), Dd: in vitro $\mathrm{D}_{3} 5 \times 10^{-5} \mathrm{M} /$ in vivo (\%50 düșük doz)

\section{In vivo'da tepraloxydim, fluazifop-p-butyl ve metribuzinin sporulasyona etkilerinin belirlenmesi}

Herbisit kullanımı öncesi sera toprak örneğinden fungus izolasyonu

Herbisit kullanım öncesi sera toprak örneklerinden fungus izolasyonu yapılarak topraktaki fungal patojenlerin belirlenmesi amaçlanmıştır. Fungus izolasyonu için seyreltme metodu uygulanmıştır (Waksman 1922, Halkman 1995). Petriler $25 \pm 1^{\circ} \mathrm{C}$ 'de inkübe edilmiştir.

Fungusların teșhisi

Fungus izolasyonları, sürvey alanından toplanan hastalıklı bitki örneklerinden gerçekleştirilmiştir. Hastalıklı bitki organları (kök, gövde, yaprak ve çiçek) $3 \mathrm{kez}$ saf su ile yıkanıp, hastalık belirtisi gösteren organların nekroze olmuş dokularından $1 \mathrm{~cm}$ büyüklügü̈nde kesitler alınmıştır. Kesitler \%10'luk $\mathrm{NaOCl}$ çözeltisinde 5 dakika süreyle yüzey dezenfeksiyonuna tabi tutulmuş ve $3 \mathrm{kez} 1$ 'er dakikalık süre ile steril su uygulaması yapılmıştır. Petriler $25 \pm 1{ }^{0} \mathrm{C}$ 'de inkübe edilmiştir. Kolonilerden öze yardımıyla alınan parçalar SNA ve Pepton Agar ortamına alınarak morfolojik yapıları incelenmiştir.

Çalışmada A. alternata, R. solani, S. solani, P. destructiva, Rh. stolonifer, F. solani, $C$. fulvum ve $U$. atrum'un periyodik olarak incelenen örneklerinde oluşan 
yapılar stereo mikroskop ve 1şı mikroskobu ile konidi, rizoid, sporangiospor, ascus, ascocarp ve askospor yapılarına bakılarak incelenmiş ve teşhisleri gerçekleştirilmiştir. Teşhisler ilgili literatüre göre yapılmıştır (Barnett and Hunter 1972, Gerlach and Nirenberg 1982, Arx 1987, Hasenekoğlu 1999).

Deneme parsellerine fungus inokulasyonu

Fungus inokulasyonu için 10 günlük taze fungal kültüre $20 \mathrm{ml}$ saf su eklenmiş, eklenen suya $\% 0.05^{\prime}$ lik Tween 80 'den $5 \mathrm{ml}$ ilave edilerek cam spatül ile karıştırılmıştır. Beherlere $25 \mathrm{ml}$ spor süspansiyonu, $10 \mathrm{~g}$ mısır unu ve $65 \mathrm{ml}$ steril su konularak 20 dakika karıştııılmış ve ağız kısmı alüminyum folyo ile kapatılarak hava ile teması kesilmiştir. İnkübatörde $25 \pm 1^{\circ} \mathrm{C}$ 'de inkübe edilmiştir (Papavizas and Davey 1962, Williams and Asher1996, Ramamoorthy et al. 2002, Erol 2007).

Deneme parsellerinde $10 \mathrm{~cm}$ derinliğinde fide çukurları açılmıştır. Aşılama öncesi parsellerdeki toprak nemlendirilmiştir ( $\% 90 \mathrm{ml} /$ parsel). Fungus inokulasyonunda kullanılacak spor süspansiyonlarının hazırlanmasında Thoma lamı kullanılmıştır. Her bir çukura $1.5 \times 10^{3}$ spor/çukur olacak şekilde ölçülendirilmiş plastik el spreyi (1 litre) yardımıyla fungus inokulasyonu gerçekleştirilmiştir. Herbisitler, fidelerin dikiminden 10 gün sonra uygulanmış ve spor sayımları yapılmıştır (Papavizas and Davey 1962, Williams and Asher 1996, Ramamoorthy et al. 2002, Erol 2007).

Deneme serasında uygulanacak herbisit dozları ve uygulanmas1

Herbisit dozları, ruhsatlı kullanım dozları dikkate alınarak hesaplanmış ve uygulanmıştır. Herbisitlerin ruhsatlı (önerilen) dozunun \%50 fazlası yüksek doz (Yd), ruhsatlı kullanım doz miktarı normal doz $(\mathrm{Nd})$ ve ruhsatlı kullanım dozunun \%50 azı ise düşük doz (Dd) olarak adlandırılmıştır. Çalışmada kullanılan herbisit uygulama alanı 0.067 da olup, doz değerleri bu alan üzerinden hesaplanmıştır (Çizelge 1). Herbisitlerin uygulanmasında 201 kapasiteli plastik sırt pülverizatörü kullanılmıştır (Özdesan, Zipo16, Konya). Herbisitler toprak sathına tozlanma şeklinde püskürtme yapılarak uygulanmıştır.

\section{In vitro'da tepraloxydim, fluazifop-p-butyl ve metribuzin içerikli sera toprak örneklerinde fungusların spor sayımı}

Deneme alanından $10 \mathrm{~cm}$ derinlikten steril toprak burgusu (Özel yapım, Elazı̆̆), toprak numune alma aparatı (Loyka, KS S100, İstanbul) ve standart numune alma sondası (Loyka, ÇNS 100-30, İstanbul) yardımıyla alınan herbisit içerikli toprak örneklerinde fungus spor sayımı toprak seyreltme metodu ile belirlenmiştir (Waksman 1922). Steril $250 \mathrm{ml}$ 'lik beher içerisine $10 \mathrm{~g}$ toprak örneği (toprak+herbisit+fungal patojen) alınarak $90 \mathrm{ml}$ karışıma ( $85 \mathrm{ml}$ 'lik fizyolojik su + 5 ml'lik Tween 80) konulmuş ve 30 dakika çalkalanmıştır (Özkalp ve Durak 1998, Oskay 2007). Seyreltme faktörü $10^{5}$ olarak belirlenmiştir (Waksman 1922, Hasenekoğlu 1989). Topraktan alınan örnekten hazırlanan ve örnekleme metoduyla oluşturulan spor süspansiyonundan otomatik pipetle $0.01 \mathrm{ml}$ alınarak mikroskopta 
Tepraloxydim, fluazifop-p-butyl ve metribuzin herbisitlerinin toprak kökenli bazı fungal patojenlerin koloni gelişimine ve sporulasyonuna etkisi

incelenmiş ve $1 \mathrm{ml}$ 'de elde edilen spor sayısı dilüsyon faktörü ile çarpılarak değer belirlenmiştir.

\section{Verilerin değerlendirilmesi}

Hesaplamalar sonucu elde edilen yüzde etki değerlerine açı transformasyonu uygulanarak denemelerde karakterler arasındaki farklılıkların önem dereceleri varyans analizi (ANOVA) ile belirlenmiş ve Duncan testi kullanılarak ortalamalar karşılaş̧ırılmıştır $(\mathrm{P} \leq 0.05)$.

\section{SONUÇLAR}

\section{Araştırmanın yürütüldüğğ seradaki iklimsel veriler}

Çalışmanın yürütüldüğü serada ortalama en düşük iç sıcaklık $21^{\circ} \mathrm{C}$ ile 2013 yılının Mart ayında, en yüksek sicaklık ise $41^{\circ} \mathrm{C}$ ile 2013 yılının Temmuz ayında ölçülmüştür. Oransal nem değeri ise 3 dönemlik domates yetişme döneminde \%71 ile \%88 arasında değişmiştir. Sera toprak sıcaklığ 1 domates yetişmesini sınırlayacak değerlerde değildir. En düşük toprak sıcaklığ $17^{\circ} \mathrm{C}$ ile 2012 yılının Mart ayında, en yüksek toprak sıcaklık değeri ise $29^{\circ} \mathrm{C}$ ile 2013 yılının Temmuz ayında belirlenmiştir (Çizelge 2).

Çizelge 2. Araştırmanın yürütüldüğü 2012-2014 yılları arasında cam seradaki iklimsel veriler

\begin{tabular}{|c|c|c|c|c|c|c|c|c|}
\hline Yll & İklim Faktörleri & Mart & Nisan & Mayıs & Haziran & Temmuz & Ağustos & Eylül \\
\hline \multirow{3}{*}{2012} & Sera iç sıcaklı $\breve{g}_{1}{ }^{\circ} \mathrm{C}$ & 22 & 27 & 31 & 33 & 40 & 37 & 35 \\
\hline & Toprak sıcaklığ $1,{ }^{\circ} \mathrm{C}$ & 17 & 21 & 24 & 25 & 26 & 27 & 26 \\
\hline & Oransal nem, $\%$ & 88 & 78 & 79 & 75 & 77 & 78 & 85 \\
\hline \multirow{3}{*}{2013} & Sera iç sıcaklığı, ${ }^{\circ} \mathrm{C}$ & 24 & 29 & 30 & 34 & 41 & 36 & 33 \\
\hline & Toprak sıcaklığ $1,{ }^{\circ} \mathrm{C}$ & 16 & 22 & 24 & 26 & 29 & 28 & 25 \\
\hline & Oransal nem, $\%$ & 85 & 79 & 77 & 81 & 72 & 76 & 75 \\
\hline \multirow{3}{*}{2014} & Sera iç sıcaklığı, ${ }^{\circ} \mathrm{C}$ & 21 & 26 & 29 & 32 & 38 & 36 & 32 \\
\hline & Toprak sıcaklığ $1,{ }^{\circ} \mathrm{C}$ & 18 & 19 & 21 & 23 & 26 & 27 & 26 \\
\hline & Oransal nem, $\%$ & 86 & 85 & 79 & 76 & 71 & 76 & 79 \\
\hline
\end{tabular}

\section{Deneme alanının toprak analiz sonuçları}

Araştırmanın yürütüldügü yıllarda, seradan, çeşitli derinliklerden alınan toprak örneklerinin fiziksel ve kimyasal özelliklerine göre organik madde oran1 $\% 1.13$, toplam azot \%0.06, kum oran1 \%53.4, kil oran1 \%20.6, pH 6.8, tuz değeri 1.67 $\mathrm{dS} / \mathrm{m}$, toplam kireç \%3.01 olarak belirlenmiştir.

\section{Deneme alanının sulama verileri}

Çalışmada deneme parsellerine 2014 y1lı domates yetiştirme döneminde bitkilere yedi günlük sulama programı ve dört sulama uygulanmıştır (Çizelge 3). Uygulanan sulama miktarları birinci sulamada $177.3 \mathrm{l} /$ parsel, ikinci sulamada $179.8 \mathrm{l} / \mathrm{parsel}$, üçüncü sulamada 203.3 1/parsel ve dördüncü sulamada ise $200 \mathrm{l} /$ parsel'dir. Dönem 
içerisinde en az su uygulaması (38.4 1/parsel) su tüketiminin az olduğu mart ayında, en yüksek su uygulamas1 (153.1 1/parsel) su tüketiminin yüksek olduğu ağustos ayında gerçekleşmiştir.

Çizelge 3. Sulama programı (/parsel)

\begin{tabular}{|l|c|c|c|c|c|}
\hline \multicolumn{1}{|c|}{ Aylar } & 1. Sulama & 2. Sulama & 3. Sulama & 4. Sulama & Toplam \\
\hline Mart & - & - & 19.2 & 19.2 & 38.4 \\
\hline Nisan & 21.0 & 21.4 & 22.0 & 22.7 & 87.1 \\
\hline Mayıs & 23.3 & 23.9 & 24.5 & 25.1 & 96.8 \\
\hline Haziran & 26.6 & 26.8 & 28.8 & 28.9 & 111.1 \\
\hline Temmuz & 35.1 & 36.9 & 40.1 & 40.7 & 152.8 \\
\hline A ğustos & 40.6 & 40.4 & 38.6 & 33.5 & 153.1 \\
\hline Eylül & 30.7 & 30.4 & 30.1 & 29.9 & 121.1 \\
\hline Toplam & 177.3 & 179.8 & 203.3 & 200 & \\
\hline
\end{tabular}

\section{Deneme alanındaki toprak örneklerinden fungus izolasyonu}

Herbisit kullanım öncesi seradaki toprak örneklerinden fungus izolasyonu yapılmış ve toprağın fungal patojenler ile bulaşık olmadığı belirlenmiştir.

Tepraloxydim, fluazifop-p-butyl ve metribuzinin fungal patojenlerin koloni gelişimine etkileri

Yaptığımız çalışma sonucunda çalışma herbisitlerinin A. alternata, $R$. solani, $C$. fulvum, $P$. destructiva, Rh. stolonifer, $F$. solani, $U$. atrum ve $S$. solani'nin koloni gelişimini engelleyici etki yaptığı belirlenmiştir. Herbisit katkılı besi yerindeki kolonilerinin genel renk görüntüsünde fark bulunmamıştır. Kolonilerin yüzeyinde sertleşme ve büzüşme olduğu gözlenmiştir. Patojenlerin misel ve hif gelişiminin olumsuz etkilendiği saptanmıştır. Engelleme oranı yüksek olan patojenlerde misel gelişmesinin yavaşladığı ve belirli bir süre sonra durduğu gözlenmiştir. $R$. solani'nin fluazifop-p-butyl'in yüksek dozunda $\left(2 \times 10^{-3} \mathrm{M}\right)$ besi yerinde hiç gelişmediği belirlenmiştir. Araştırma sonucunda, $R$. solani, Rh. stolonifer (fluazifop-p-butyl) ve $P$. destructiva (tepraloxydim)'nın düşük dozundan $\left(5 \times 10^{-5}\right.$ M) etkilenmemiştir. Herbisitlerin engelleme oranları sırasıyla; -\%0.10; -\%4.14; \%1.29 olarak gerçekleşmiştir. Bu sonuçlar, koloni gelişimi için teşvik edici bulunmuştur. Aynı doz uygulamasında metribuzin herbisitinde benzer etkiler görülmemiştir. Çalışmada kullanılan herbisitlerin fungal patojenlerin koloni gelişimine yaptığı etkiler Çizelge 4'de gösterilmiştir.

\section{Tepraloxydim, fluazifop-p-butyl ve metribuzinin fungal patojenlerin sporulasyonuna etkileri}

Araştırmamızda sera denemelerinde, tepraloxydim herbisitinin yüksek, normal ve düşük dozlarda $A$. alternata, $R$. stolonifer ve $P$. destructiva'ya fungistatik etki yaptığı saptanmıştır. Bununla birlikte herbisitlerin doz miktarının azalmasına bağlı olarak spor sayılarında artışın olduğu gözlenmiştir. Fluazifop-p-butyl'in yüksek dozunun $S$. solani ve $U$. atrum'un sporulasyonuna etkisinin diğer dozlara göre çok 
Tepraloxydim, fluazifop-p-butyl ve metribuzin herbisitlerinin toprak kökenli bazı fungal patojenlerin koloni gelişimine ve sporulasyonuna etkisi

daha etkili olduğu saptanmıştır. Normal ve düşük dozlar ise birbirine yakın denilebilecek bir etki göstermiştir. Metribuzinin $U$. atrum ve $S$. solani'nin sporulasyonuna etkisi, son sayımlarda birbirine yakın denilebilecek bir seviyede bulunmuştur.

Serada yürütülen çalışmada, domates bitkilerine tepraloxydim, fluazifop-p-butyl ve metribuzin aktif maddelerinin önerilen dozlarının \%50 fazlasının uygulanması sonucunda A. alternata spor oluşumunu sirasıyla $1.2 \times 10^{2}, 1.8 \times 10^{2}$ ve $2.8 \times 10^{2}$ spor/ml oranında engellediği tespit edilmiştir. Herbisitlerin \%50 eksik doz uygulaması için; toprakta A. alternata'nın spor oluşumu tepraloxydim uygulamasinda $2.7 \times 10^{2} \mathrm{spor} / \mathrm{ml}$, fluazifop-p-butyl uygulamasinda $3.0 \times 10^{2} \mathrm{spor} / \mathrm{ml}$ ve metribuzin uygulamasında $4.1 \times 10^{2}$ spor $/ \mathrm{ml}$ olarak gözlenmiştir. Çalışmada kullanılan herbisitlerin fungal patojenlerin sporulasyonuna yaptığ 1 etkiler Çizelge 5'de gösterilmiştir. 


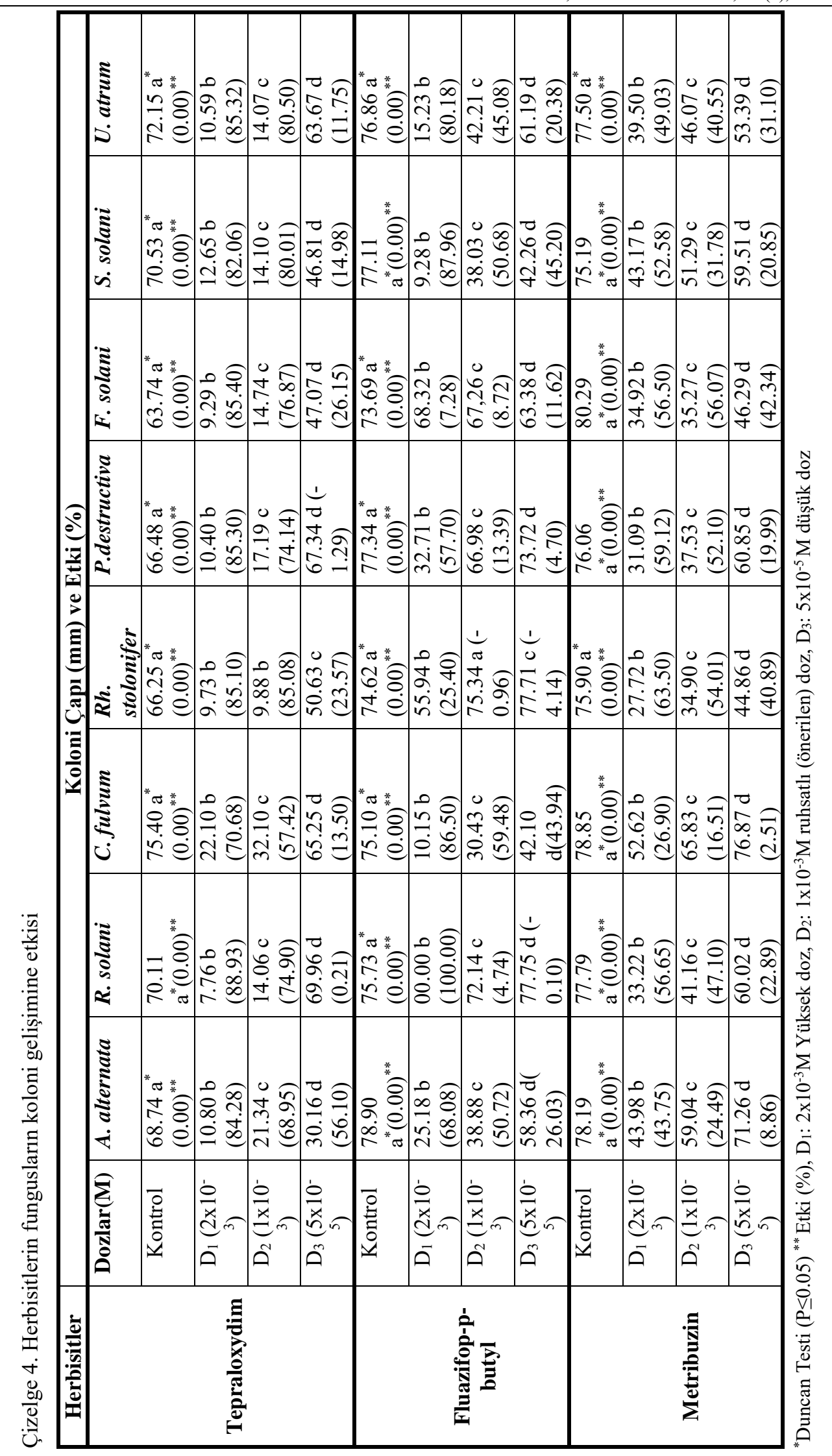




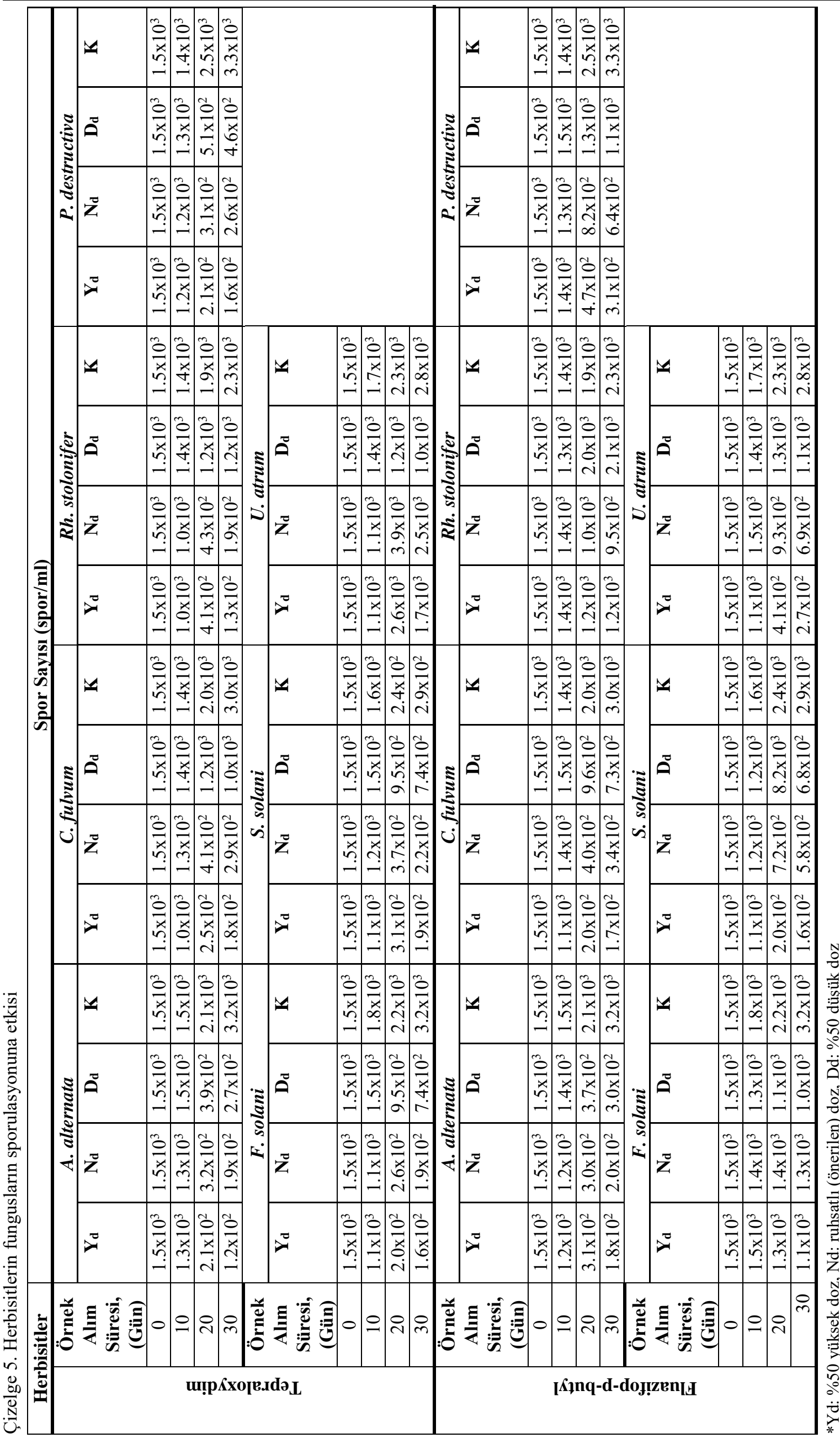




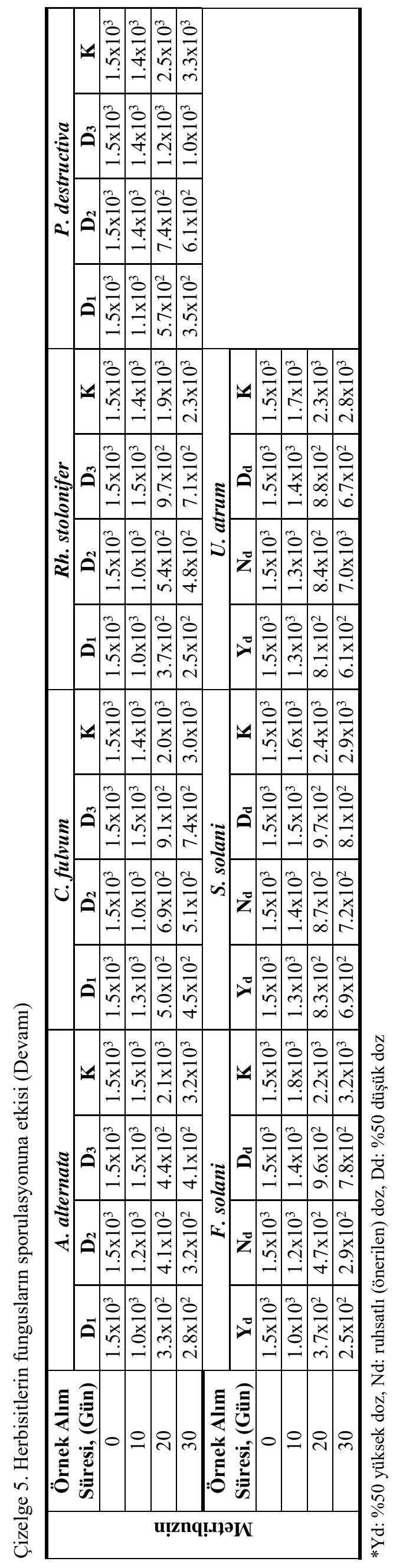


Tepraloxydim, fluazifop-p-butyl ve metribuzin herbisitlerinin toprak kökenli bazı fungal patojenlerin koloni gelişimine ve sporulasyonuna etkisi

\section{TARTIŞMA VE KANI}

Bu çalışma Elazığ bölgesi domates üretim alanlarında son zamanlarda artan fungal hastalıkların sebeplerinin araştırılması amacıyla yapılmıştır. Bölgede herbisit patojen etkileşimini araştıran bir çalışmanın yapılmamış olması nedeniyle bu çalışma bir ilki teşkil etmektedir. Çalışma herbisitleri seçilirken bölgede en çok kullanılan herbisitler (tepraloxydim, fluazifop-p-butyl ve metribuzin) dikkate alınmıştır. Çalışmada kullanılan herbisitler ile fungal patojenlerarasında etkileşim gösteren bir literatüre rastlanmamıştır. Bu nedenle sonuçlara yönelik tartışma ele aldığımız patojenlere karşı kullanılmış farklı herbisitler ile ilgili çalışmalar ile yapılmıştır.

Mevcut ortamdaki sıcaklık ve oransal nemin artması fungal patojenlerin yaşamsal alanlarının genişlemesinde en önemli faktörlerdendir. Çalışmanın yürütülmesi esnasında düzenli ölçümlerle çalışmaya olan etkisi belirlenmiştir. Çalışmanın yürütüldüğ̈̈ serada ortalama en düşük iç sıcaklık $21^{\circ} \mathrm{C}$ ile 2013 y1lının Mart ayında, en yüksek sıcaklık ise $41^{\circ} \mathrm{C}$ ile 2013 yılının Temmuz ayında ölçülmüştür. $\mathrm{Bu}$ değerlerin serada yaptığımız çalışma sonuçlarını etkilemediği saptanmıştır. Oransal nem değerinin 3 dönemlik domates yetiștirme sezonunda $\% 71$ ile $\% 88$ arasında değişmesinden dolayı domates bitkisinde ve fungal patojenlerin yayılmasında etkisi gözlenmemiştir. En düşük toprak sıcaklığ $17^{\circ} \mathrm{C}$ ile 2012 yılının Mart ayında, en yüksek toprak sıcaklık değeri ise $29^{\circ} \mathrm{C}$ ile 2013 yılının Temmuz ayında belirlenmiştir. Sera toprak sıcaklığı domates yetişmesini sınırlayacak değerlerde değildir.

Araştırmamızda sera deneme parsellerine domates yetiştirme döneminde bitkilere yedi günlük sulama programı uygulanmıştır. Sulama, toprak kökenli fungal patojenlerin yayılmasını ve yaşamsal alanlarını kısıtlamayacak şekilde ayarlanmıştır. Bu nedenle Çizelge 3'de verilen sulama miktarları kullanılmıştır. Sulama konusunda yapilacak hatanın ortamdaki mevcut olan fungal patojenlerin yaşamsal alanını değiştireceği ve çalışma sonuçlarını etkileyeceği düşünülmektedir. $\mathrm{Bu}$ amaçla sulama kontrollü olarak verilerek bitkinin tüketmesi sağlanmıştır. Yücel ve ark. (2013) tarafından yapılan bir çalışmada, sulamanın toprak kökenli fungal patojenlerden $F$. oxysporum, $F$. solani ve Macrophomina phaseolina'ya etkisinin olduğunu ve kontrolsüz yapılacak bir sulamanın ortamdaki fungal hastalıkları artıracağını saptamışlardır. Yapılan çalışma çalışmamızı doğrular niteliktedir.

Gelişigüzel kullanılan herbisitler nedeniyle de toprak kökenli patojenlerin büyük bir çoğunluğunda dayanıklılık mekanizması aktif hale gelmiş ve yeni oluşturdukları nesillere de aktarmışlardır. Herbisit ile fungal patojenler arasındaki etkileşimi araştırmak için Özer ve ark. (1997) yaptıkları çalışmada, toprakta bulunan patojenlerle herbisitlerin etkinliği arasında önemli ilişkilerin bulunduğunu tespit etmişlerdir. Çalışmada $R$. solani ile bulaşı toprağa tillam ve pyrazon herbisitleri uygulandığında, $R$. solani'nin popülasyon yoğunluğunun artarak 
çimlenen şekerpancarı fidelerine önemli zararlar verdiğini ve hastalık şiddetinde de artış olduğunu bildirmişlerdir.

Tepraloxydim etken maddeli herbisitin in vitro' da yüksek doz seviyesinde $\left(2 \times 10^{-3}\right.$ M) $R$. solani'nin \%88.93, A. alternata'nın \%84.28, C. fulvum'un \%70.68, $R h$. stolonifer'in \%85.31, S. solani'nin \%82.06, $U$. atrum'un \%85.32, $P$. destructiva'nın \%84.35 ve $F$. solani'nin \%85.42 gelişimini engellediği ve misel oluşumunu olumsuz etkilediği tespit edilmiştir. In vitro'da yapılan çalışmada Sanogo et al. (1999), glyphosate ve lactofen'nin $F$. solani'nin konidial çimlenmesini, misel oluşumunu, büyümesini ve spor oluşumunu azalttığını bildirmiştir. Bu çalışmada kullanılan herbisitlerin çalışmamızdaki herbisitlerden farklı olmasına rağmen elde edilen sonuçların çalışmamızla uyumlu olduğu düşünülmektedir.

Serada yaptığımız denemeler sonucunda, $0-10 \mathrm{~cm}$ toprak aralığından alınan örneklerin incelenmesinde patojenlerin spor sayılarında önemli derecede azalmanın olduğu tespit edilmiştir. Yüksek doz uygulamasında en fazla etkinin A. alternata ve Rh. stolonifer'de gerçekleştiği saptanmıştır. Bunlardan A. alternata'nın spor sayısı $1.2 \times 10^{2} \mathrm{spor} / \mathrm{ml}$, Rh. stolonifer' in ise $1.3 \times 10^{2} \mathrm{spor} / \mathrm{ml}$ olarak bulunmuştur. Düşük doz uygulamasında en yüksek etkinin A. alternata' ya karş1 gerçekleştiği ve spor sayısının da $2.7 \times 10^{2}$ spor/ml olduğu tespit edilmiştir. Veselinovska et al. (2013), trifluralin etken maddeli herbisitin topraktaki toplam fungus sayıs üzerinde engelleyici bir etkiye sahip olduğunu saptamışlardır. Ayrıca, trifluralin kullanılan alanlarda toprak derinliğinin $0-10$ ve $10-20 \mathrm{~cm}$ aralığında fungus sayılarının çok daha ciddi oranda etkilendiğini bildirmişlerdir. Sera şartlarında kullandığımız herbisitlerin (tepraloxydim, fluazifop-p-butyl ve metribuzin) olumsuz yönde etkilerinin olduğu gözlenmiştir. Bu çalışmada kullanılan herbisit etken maddesinin farklı olmasına rağmen sonuçların benzerlik gösterdiğine inanılmaktadır.

Çalışmamızda $2 \times 10^{-3} \mathrm{M}$ yüksek doz seviyesinde metribuzinin $R h$. stolonifer'in koloni gelişimini $\% 63.47$ oranı ile en yüksek seviyede, $5 \times 10^{-5} \mathrm{M}$ doz seviyesinde ise C. fulvum gelişimini \%2.51 ile en düşük seviyede engellediği belirlenmiştir. Ayrıca araştırmanın açık alanda yürütüldüğü toprakların azot referans aralığının $\% 0.02-2.5$, sera toprağındaki azot değerinin ise \%0.056 olarak belirlenmesinden dolayı, metribuzinin azot alımına etkisinin önemsenmeyeceği sonucuna varılmıştır.

Tammy and Glenn (1991), metribuzinin A. solani'ye karşı toksik etki yapmadığını ve herbisitin Alternaria cinsine ait diğer bir tür olan A. alternata'ya etkisinin fazla olmadığını bildirmişlerdir. Çalışma sonucunda elde edilen bulgular yürütülen bu çalışmayla benzerlik göstermiştir.

Araştırmamız ve yapılan diğer çalışmalar sonucunda birçok herbisitin etki mekanizmalarının funguslardaki biyokimyasal süreçlere etki ederek stabil, olumlu veya olumsuz etkilerinin olduğu belirlenmiştir. Herbisitlerin fungusları, hücre organlarının görevini yapamaz hale gelmesi, solunumun engellemesi, protein sentezine etkisi, hücre çoğalmasına etki etmesi gibi sonuçlarla etkilediği 
Tepraloxydim, fluazifop-p-butyl ve metribuzin herbisitlerinin toprak kökenli bazı fungal patojenlerin koloni gelişimine ve sporulasyonuna etkisi

bilinmektedir (Özer ve ark. 2001). Yaptı̆̆ımız çalışma sonucunda fluazifop-pbutyl'in yüksek doz $\left(2 \times 10^{-3} \mathrm{M}\right)$ seviyesinde $R$. solani'nin kolonisinin gelişimini $\% 100$ oranı ile en yüksek seviyede, $5 \times 10^{-5} \mathrm{M}$ dozda ise $P$. destructiva'nın koloni gelişimini \%4.68 ile en düşük seviyede engellediği saptanmıştır. Herbisitin $R$. solani'nin protein sentezini ve hücre çoğalmasını yüksek oranda engellediği düşünülmektedir. Benzer bir çalışmada Abdel-Mallek et al. (1994), fluazifop-pbutyl'in, toprak funguslarının oksijen alımı üzerine olumsuz etkilerini belirlemiş ve herbisitin 63 ve $0.3 \mu \mathrm{g} / \mathrm{g}^{-1}$ dozlarının fungus yoğunluklarına önemli derecede etkilediğini saptamışlardır. Bu çalışmaların sonuçları ve bulguları, yürüttüğümüz çalışmadaki bulgu ve sonuçlarla benzerlik göstermektedir. Diğer bir çalışmada Starrat and Lazarovits (1996), domates yetiştiriciliğinde sorun olan $F$. oxysporum'a karşı acetochlor etken maddeli herbisitin etkisini araştırmışlar ve herbisitin domates bitkisinin biyokimyasal yapısındaki serbest amino asit seviyesinde değişme yapmadığını saptamışlardır. Amino asit seviyesinin stabil kalması sonucunda bitkide solgunluk hastalığına neden olan $F$. oxysporum f. $\mathrm{sp}$. lycopersici'ye karşı dayanıklılık oluşmadığını tespit etmişlerdir. Yaptığımız çalışmada metribuzinin fungusların koloni gelişimini artııı yönde bir etkisi bulunmamıştır. Bu çalışma da bizim çalışmamızı destekler niteliktedir.

Araştırmamızda fungal hastalıklar ile tepraloxydim, fluazifop-p-butyl ve metribuzin arasındaki etkileşimin ortaya çıkmasında; kullanılan tarımsal ilaçların büyük çoğunluğunun etkisinin düşük ve depolanma şartlarından değişime uğrayabilecek olmas1, toprakta bulunan maddelerle kimyasal tepkimeye girerek toksik etkide bulunması, hızlı sonuç alma adına kullanım dozunun üstüne çıkılarak yüksek dozda uygulanması gibi etkenlerden kaynaklandığı tahmin edilmektedir. Fungal hastalıklarla kimyasal mücadelede bu herbisitlerin kullanılması ortamdaki mevcut fungal hastalıkların yoğunluklarını azaltarak başarı yüzdesini artıracağı düşünülmektedir. Örneğin $R$. solani ile mücadelede fluazifop-p-butyl'in kullanılması durumunda ümitvar bir sonuç olarak görülmektedir. Herbisitlerin kullanılacağı ortamlarda, mevcut fungal hastalık veya hastalıkların teknik elamanlarca belirlenmesinin ve herbisitlerin teknik elamanların kontrolünde uygulanmasının ve uygulama sonrası fungal hastalıkların takip edilmesinin büyük önem taşıdığını düşünmekteyiz. Ayrıca araştırıcıların hastalık şiddeti ve oranı yüksek olan fungal patojenlerin bulunduğu bölgelerde, sık kullanılan pestisitlerin tespitini yaparak patojenlerle aralarındaki etkileşimi araştırması gerektiğine inaniyoruz.

Sonuç olarak, tepraloxydim, fluazifop-p-butyl ve metribuzin kullanımının fungal patojenlerin bulunduğu ortamdaki popülasyonlarının azaltılmasında alternatif bir mücadele olacağ 1 ve herbisitlerin fungal patojenlere etkisinin araştırılması alanında yapılacak çalışmalara da literatür yönünden katkı sağlayacağı düşünülmektedir. 


\section{KAYNAKLAR}

Abdel-Mallek A. Y., Abdel-Kader M. I. A. and Omar S. A. 1994. Effect of the Herbicide Fluazifop-p-Butyl on Fungal Populations and Activity in Soil. Water Air Soil Pollut., 86, 151-157.

Akgül S. D. ve Canıhoş Y. 2002. Kavunda Fusarium Solgunluğuna Karşı Trifluralin ve Acetochlor Herbisitlerinin Kullanılarak Dayanıklılığının Teşvik Edilmesi. Yüksek Lisans Tezi. Çukurova Üniversitesi Fen Bilimleri Enst., Adana, 43 s.

Aktaş H. ve Şimşek Z. 2005. Çankırı Kenbağ Orman Fidanlığındaki Kavak Fidanlarındaki Cytospora Kanseri (Cytospora chrysosperma "Pers."Fr.)'nin Morfolojisi, Zararı ve Alınabilecek Önlemler. İstanbul Üniversitesi Orman Fakültesi Dergisi, A5 (2),4854.

Benjilali B., Tantadui - Elaraki A., Ayadi A. and Ihlal M. 1984. Method to Study Antimicrobial Effects of Essential Oils: Application to the Antifungal Activity of Six Moroccan Essences. J. Food Protect, 47, 748-752.

Bouyoucos G. J. 1951. A Recalibration of the Hydrometer Method for Making Mechanical Analysis of Soils. Agronomy J., 43, 434-438.

Boyraz N. ve Özcan M. 1997. Bitki Patojeni Funguslara Bazı Yerli Baharat Ekstrakt ve Uçucu Yağlarının Antifungal Etkileri. Gıda, 22(6), 457-462.

Boyraz N. ve Koçak R. 2006. Bazı Bitki Ekstraktlarının in vitro Antifungal Etkileri. Selçuk Üniversitesi Ziraat Fakültesi Dergisi, 20(38), 82-87.

Domsch K. H., Jagnow G. and Anderson T. H. 1983. An Ecological Concept for the Assessment of Side Effects of Agrochemicals on Soil Microorganisms. Residue Rew, 86, 65-105.

Deans S. G. and Svoboda K. P. 1990. The Antimicrobial Properties of Marjoram (Origanum majorana L.) Volatile Oil. Flavour Fragr. J., 5(1), 187-190.

Ecevit O. H., Mennan Aksoy H.M. ve Akça İ. 1999. Tarımsal Mücadele İlaçları ve Çevreye Olan Etkileri. O. M. Ü. Ziraat Fakültesi Ders Notları, Samsun, 145 s.

Elham M. and Mansoor, M. 2013. The Effects of Cotton and Soybean Selective Herbicides on Mycelial Growth of Rhizoctonia solani Causal Agent of Damping off. Plant Protection Journal Spring, 5(14): 99-108.

Erdoğan O., Çelik A., Yıldız Ş. ve Kökten A. 2014. Pamukta Fide Kök Çürüklüğü Etmenlerine Karşı Bazı Bitki Ekstrakt ve Uçucu Yağlarının Antifungal Etkisi. Türk Tarım ve Doğa Bilimleri Dergisi, 1(3), 398-404.

Erol F. Y. 2007. Samsun İlinde Domateste Kök ve Kökboğazı Çürüklüğü Hastalığının Yayılışı, Şiddeti ve Hastalığa Neden Olan Etmenlerin Belirlenmesi. Yüksek Lisans Tezi. T.C. Ondokuz Mayıs Üniversitesi, Fen Bilimleri Enst., Samsun, 89 s.

Halkman A. K. 1995. Mikrobiyolojide Kullanılan Besiyerleri. Ankara, 58 s.

Hasenekoğlu İ. 1989. Toprak Mikrofunguslarının İzolasyon ve Kültür Metodları. Atatürk Üniversitesi Kazım Karabekir Eğitim Fakültesi, Erzurum, 94 s.

Karman M. 1971. Bitki Koruma Araştırmalarında Genel Bilgiler. T.C. Tarım Bakanlığı Zirai Mücadele ve Zirai Karantina Genel Müdürlüğü Yayınları, İzmir, 279 s. 
Tepraloxydim, fluazifop-p-butyl ve metribuzin herbisitlerinin toprak kökenli bazı fungal patojenlerin koloni gelişimine ve sporulasyonuna etkisi

Oskay F. 2007. Çankırı İli Eldivan İlçesi Karaçam Orman Topraklarındaki Fungal Floranın ve in vitro'daki Antagonistik Etkileşimlerinin Belirlenmesi. Yüksek Lisans Tezi. Ankara Üniversitesi Fen Bilimleri Enst., Ankara,100 s.

Özer Z., Kadığlu İ., Önen H. ve Tursun N. 1997. Herboloji. Gaziosmanpaşa Üniversitesi, Ziraat Fakültesi Yayınları, Tokat, 388 s.

Özer Z., Kadığlu İ., Önen H. ve Tursun N. 2001. Herboloji. Gaziosmanpaşa Üniversitesi Ziraat Fakültesi Yayınları. Tokat, 409 s.

Özkalp B. ve Durak Y. 1998. Konya ve Civarı Küflü Peynirlerinde Küf Florasının Araştırılması. Tr. J. Biology, 22, 341-346

Papavizas G. C. and Davey C. B. 1962. Isolation and Pathogenicity of Rhizoctonia Saprophytically Existing in Soil. Phytopathology, 52, 834-840.

Ramamoorthy V., Raguchander T. and Samiyappan R. 2002. Enhancing Resistance of Tomato and Hot Pepper to Pythium diseases by Seed Treatment With Fluorescent Pseudomonas. European Journal of Plant Pathology, 108, 429-441.

Sanogo S., Yang X. B. and Scherm H. 1999. Effects of Herbicides on Fusarium solani f. sp. glycines and Development of Sudden Death Syndrome in Glyphosate-Tolerant Soybean. Phytopathology, 90, 57-66.

Starratt A. N. and Lazarovits G. 1996. Increases in Free Amino Acid Levels in Tomato Plants Accompanying Herbicide-Induced Disease Resistance. Pesticide Biochemistry and Physiology, 54, 230-240.

Şevik M. A., Mennan H. ve Sökmen M. A. 2004. Herbisitlerin Bitki Patojenlerine Etkisi. OMÜ Zir. Fak. Dergisi, 19(1), 50-55.

Tammy L. H. and Glenn W. S. 1991. Interactive Effects of the Fungicide Chlorothalonil and the Herbicide Metribuzin Towards the Fungal Pathogen Alternaria solani. Bull. Environ. Contam. Toxicol., 47, 97-103.

Torun H., Uygur S. ve Uygur F. N. 2011. Çukurova Bölgesi'nde Bazı Kültür Bitkileri Üzerinde Farklı Dozlardaki Herbisit Uygulamalarının Oluşturduğu Zararlanmalar. Türkiye IV. Bitki Koruma Kongresi Bildirileri, 28-30 Haziran, Kahramanmaraş, $174 \mathrm{~s}$.

Veselinovska S., Jordan Z. and Todorovska A. 2013. Effect of Trifluraline Herbicide on Soil Microflora in Tomato Seedlings in Outdoor Conditions in Black Forest, Stip Area. Proceedings of Seminar of Ecology. 25- 26 April, Sophia, Bulgaria, 189-197.

Waksman S. A. 1922. A Method Counting the Numbers of Fungi in the Soil. Bact., 7, 339341.

Williams G. E. and Asher M. J. C. 1996. Selection of Rhizobacteria for the Control of Pythium ultimum and Aphanomyces cochlioides on Sugar Beet Seedlings. Crop Protection, 15 (5), 479-486.

Yücel S., Günaçtı H. ve Sezen M.S. 2013. Salçalık Biber Yetiştiriciliğinde Farklı Sulama Yöntemlerinin Toprak Kökenli Hastalık Çıkışı ve Verime Etkileri. Derim, 30 (2),1121 